\section{Tekstikriitikot verkostoituivat}

Torstaina 24. toukokuuta joukko tekstikritiikin alan tutkijoita kokoontui Suomalaisen Kirjallisuuden Seuraan perustamaan valtakunnallista tekstikritiikin ja tieteellisten editioiden Variantti-tutkijaverkostoa. Paikalla oli kolmisenkymmentä tutkijaa ja muistiorganisaatioiden edustajaa kuudesta eri kaupungista. Edustetut tutkimusalat vaihtelivat klassillisesta filologiasta teologiaan ja historiasta kirjallisuudentutkimukseen.

Perustamistilaisuuden olivat kutsuneet koolle Suomalaisen Kirjallisuuden Seuran EDITH - Suomalaisen kirjallisuuden kriittiset editiot -yksikkö sekä systemaattisen teologian tutkijatohtori Olli Hallamaa ja akatemiatutkija, yleisen historian ja kirkkohistorian dosentti Tuomas Heikkilä Helsingin yliopistosta.

Suomessa laaditaan aktiivisesti tieteellisiä editioita koti- ja ulkomaisesta kirjallisuudesta, mutta alan yhteistyö on ollut tähän asti pitkälti tutkimusalakeskeistä. Perustettu Variantti-verkosto pyrkii muun muassa edistämään tekstikritiikin alan tuntemusta, tiedotusta ja metodologista keskustelua sekä editiohankkeiden välistä yhteistyötä.

Verkosto on avoin kaikille tekstikritiikistä ja tieteellisistä editioista kiinnostuneille. Editiohankkeissa työskentelevien tutkijoiden ohella Variantti pyrkii yhdistämään myös muita tekstikritiikin alaa sivuavia tutkijoita ja muita toimijoita. Kirjallisuudentutkimuksen piirissä Variantin toimintatavoitteita lähellä ovat muun muassa käsikirjoitusten tutkimus, geneettinen teoria ja kirjahistoria sekä sähköisiä korpuksia hyödyntävä tutkimus.

Verkoston toiminnasta tiedotetaan sähköpostilistalla, jolle kuka tahansa voi liittyä ottamalla yhteyttä listan ylläpitäjään osoitteeseen owner-variantti-verkko@helsinki.fi. Variantin verkkosivut perustetaan osoitteeseen www.edith.fi/ variantti, jossa on jo saatavilla joitakin perustietoja verkostosta ja josta pääsee alaan liittyvälle linkkisivustolle.

\section{Sakari Katajamäki}

Lisätietoja saa EDITHin erikoistutkija Sakari Katajamäeltä (sakari.katajamaki@ finlit.fi; p. 0201 131285). 